\title{
Prior mucosal exposure to heterologous cells alters the pathogenesis of cell-associated mucosal feline immunodeficiency virus challenge
}

\author{
Surender B Kumar*1,2,3, Sarah Leavell1,2, Kyle Porter ${ }^{4}$, Barnabe D Assogba1,2,3 and Mary J Burkhard1,2,3
}

\begin{abstract}
Background: Several lines of research suggest that exposure to cellular material can alter the susceptibility to infection by HIV-1. Because sexual contact often includes exposure to cellular material, we hypothesized that repeated mucosal exposure to heterologous cells would induce an immune response that would alter the susceptibility to mucosal infection. Using the feline immunodeficiency virus (FIV) model of HIV-1 mucosal transmission, the cervicovaginal mucosa was exposed once weekly for 12 weeks to 5,000 heterologous cells or media (control) and then cats were vaginally challenged with cell-associated or cell-free FIV.
\end{abstract}

Results: Exposure to heterologous cells decreased the percentage of lymphocytes in the mucosal and systemic lymph nodes (LN) expressing L-selectin as well as the percentage of CD4+CD25+T cells. These shifts were associated with enhanced ex-vivo proliferative responses to heterologous cells. Following mucosal challenge with cell-associated, but not cell-free, FIV, proviral burden was reduced by $64 \%$ in cats previously exposed to heterologous cells as compared to media exposed controls.

Conclusions: The pathogenesis and/or the threshold for mucosal infection by infected cells (but not cell-free virus) can be modulated by mucosal exposure to uninfected heterologous cells.

\section{Background}

In the early 1990s, immunization against major histocompatibility complex (MHC) alloantigens was proposed as a potential human immunodeficiency virus (HIV)-1 vaccine strategy [1]. Recently, interest in the potential of alloprotection against HIV-1 transmission has gained new momentum with the findings that allogeneic mismatch may be associated with reduced sexual and vertical transmission.

Animal model vaccine studies suggest that exposure to heterologous antigens play a role in protection against lentiviral infection. In simian immunodeficiency virus (SIV) and feline immunodeficiency virus (FIV) studies, the efficacy of cell-based vaccines has been shown to be, at least in part, due to immune responses against the heterologous cells [2-8]. In the SIV system, this protective mechanism has further been delineated as both humoral

* Correspondence: kumar.145@osu.edu

1 Department of Veterinary Biosciences, The Ohio State University, Columbus, Ohio, USA

Full list of author information is available at the end of the article and cell-mediated responses against MHC molecules [2$5,9,10]$. Consistent with animal model studies are epidemiological reports that support a role for alloantigen driven immune responses in HIV-1 resistance. For example, women who have less common human leukocyte antigen (HLA) types for their region are over-represented in cohorts of sex workers who remain seronegative despite repeated high-risk exposure [11].

While more studies are required to ascertain if susceptibility to HIV-1 infection, disease progression, or both are associated with certain HLA clusters, the protective role for induced immunoreactivity against HLA antigens appears to be well established $[1,12,13]$. Alloimmune responses can provide both neutralizing antibody [14] and cell-mediated [14-16] antiviral activity against HIV-1 and alloimmunization of women elicits a dose dependent decrease in the susceptibility of CD4+ T-cells to in vitro HIV-1 infection [17]. Similar anti-HLA immune responses have been identified in exposed seronegative sex workers [17-19] and infants born to HIV-1-infected mothers [20]. 
Alloantigen exposure can directly modulate the production of soluble factors and cell surface receptors. Alloimmunization has been shown to elicit CD8+ T-cell anti-HIV-1 activity as well as production of RANTES, MIP- $1 \alpha$ and $\beta$ [16]. Importantly, sexual contact may be sufficient to induce alloimunization that alters the expression of $\mathrm{HIV}-1$ receptors. This was demonstrated by finding that CD4+ T cells from women with unprotected sexual activity were highly resistant to binding by either CCR5 or CXCR4 strains of HIV-1 [21].

Taken together, there is strong evidence that exposure to heterologous cells and allogenic material alters the susceptibility of cells to lentiviral infection. However, whether this translates into reduced host infection or altered pathogenesis is less well understood. The role of cell exposure is particularly relevant when considering mucosal transmission. Not only is mucosa the major route of cell-free and cell-associated HIV-1 transmission [22-25], the vaginal and rectal mucosa is commonly exposed to heterologous cells and allogeneic material during sexual activity. Ejaculates contain HLA antigen expressing CD4+ $\mathrm{T}$ cells, macrophages, neutrophils, germ cells, epithelial cells and to some extent spermatozoa [26].

Given the reports of seronegativity in cohorts of sex workers with high-risk exposure [11], we hypothesized that HIV-1 transmission or progression could be altered by prior or concurrent immune stimulation by mucosal exposure to heterologous cells. We addressed this question directly using the FIV animal model of vaginal HIV-1 transmission. We repeatedly exposed cats by mucosal exposure to heterologous cells or media, assayed for lymphocyte phenotype as well as proliferative responses against cellular material, and then vaginally challenged cats with either cell-associated or cell-free FIV. We found that prior exposure to heterologous cells induced an immune response that was associated with reduced viral burden after mucosal challenge with cell-associated, but not cell-free, FIV.

\section{Methods}

\section{Experimental design}

To maximize genetic diversity, 22 female (Liberty Laboratory) and 6 male (Harlan Laboratories) SPF cats were obtained, housed, acclimated, and cared for in accordance with the standards of the American Association of Accreditation of Laboratory Animal Care and The Ohio State University Institutional Animal Care and Use Committee. Peripheral blood mononuclear cells (PBMC) from each female cat were tested against irradiated cells from each male cat in a one-way mixed lymphocyte reaction (MLR). The four male cats whose cells induced the highest MLR proliferation were used as sources of heterologous cells for this study. Female cats ( $\mathrm{n}=11$ per group) were vaginally exposed once weekly for 12 weeks to lymphocyte media (Media) or 5000 male lymphocytes (Cells) in $50 \mu \mathrm{l}$ final volume of lymphocyte media. For exposure inocula, male lymphocyte samples were not pooled. Female cats were exposed to heterologous cells from a different male cat each week for four weeks and then the cycle was repeated. One week after the $12^{\text {th }}$ exposure, three animals from each exposure group were euthanized to collect blood and tissue samples to evaluate tissue immune responses. Tissue samples were collected from the popliteal lymph node (PLN), mesenteric lymph node (MLN), medial iliac lymph node (ILN), small intestinal intraepithelial lymphocytes (IEL), and small intestinal lamina propria lymphocytes (LPL). One week after the $12^{\text {th }}$ exposure, the remainder of the cats from each group $(\mathrm{n}=8)$ were vaginally challenged with cell-associated $(\mathrm{n}=$

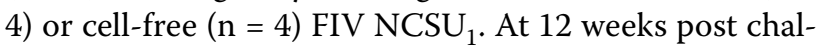
lenge (PC), blood, lymph nodes (popliteal, mesenteric, medial iliac) and gut (both IEL and LPL) were obtained at necropsy to quantify tissue viral load and examine immune responses. Mucosal exposure, viral inoculation, and venipuncture were performed under anesthesia induced by intravenous tiletamine and zolazepam (Telazol, Fort Dodge Animal Health, Fort Dodge, IA).

\section{Virus inocula}

Cats were inoculated with either $5 \times 10^{5}$ FIV-infected Mya- 1 cells (cell-associated challenge) or $50 \times \mathrm{TCID}_{50}$ tissue culture supernatant (cell-free challenge). Both inocula were infected with FIV-NCSU 1 an A-clade FIV. To obtain cell-associated inocula, Mya-1 T-cells were cultured for three days in complete RPMI 1640 lymphocyte media containing 20\% fetal bovine serum (Atlanta Biologicals, Norcross, Ga.), $1 \mathrm{mM}$ sodium pyruvate, $0.1 \mathrm{mM}$ Hepes buffer sodium, $5 \times 10^{-5} \mathrm{M} \beta$-2-mercaptoethanol, $100 \mathrm{U}$ of penicillin/ml, $100 \mu \mathrm{g}$ of streptomycin/ml (all from Invitrogen Life Sciences) and $100 \mathrm{U} / \mathrm{ml}$ recombinant human interleukin-2 (IL-2) kindly provided by the $\mathrm{NIH}$ AIDS Research and Reagent Program at $37^{\circ} \mathrm{C} 5 \%$ $\mathrm{CO}_{2}$, and then infected with $20 \times \mathrm{TCID}_{50}$ cell-free FIV$\mathrm{NCSU}_{1}$ tissue culture supernatant. At day 5 post-infection, infected cells were harvested and frozen in liquid nitrogen until use, with aliquots saved to analyze the degree of infectivity by real-time PCR, co-culture with feline CD4+ indicator cells [27], immunocytochemistry and western blot. For immunocytochemistry, cells were incubated with $1 / 1000$ of serum from a chronically FIVinfected cat at $37^{\circ} \mathrm{C}$ for $30 \mathrm{~min}$, probed with goat anti-cat IgG-FITC (USB Corporation, Cleveland, $\mathrm{OH}$ ), and fixed with $2 \%$ paraformaldehyde. Fluorescence was monitored by confocal imaging system LEICA TCS SP2 AOBS (Leica Microsystems, Exton, PA) and 98\% of the cells were infected. This correlated with real-time PCR and 
co-culture assays indicating at least one in ten cells was infected. Cell lysates were probed with 1:1000 anti-gp120 (SU1-30) (Custom Monoclonals International, Sacramento, CA) to confirm expression of FIV Env [28].

\section{Sample processing}

PBMC and lymphocytes from the distal jejunum, popliteal, mesenteric, and medial iliac lymph nodes were processed as previously described [29-31]. Intraepithelial lymphocytes (IEL) and lamina propria lymphocytes (LPL) were isolated from 10 inches of distal jejunum following excision of Peyer's patches and lymphoid follicles [30,31]. Cells were either used immediately (T-cell phenotype and proliferation assays) or were washed, treated, and pelleted (DNA, RNA or protein extraction).

\section{Real time (RT)-PCR}

DNA was purified from PBMC and tissue lymphocytes using DNeasy Tissue Kit (Qiagen, Valencia, CA). A conserved region (170-bp) of FIV-gag was amplified from $150 \mathrm{ng}$ of each sample with primers $\mathrm{GagNCSU}_{1}-1247$ sense (5'-GCTTAAAGCAATTGACGGCAGAGTATGATCG-3') and GagNCSU ${ }_{1}-1417$ anti-sense (5'-CCTCGAGATACCATGCTCTACACTGCATCC-3')

previously described [28]. Proviral copies were expressed as gag copies per million GAPDH copies [31]. The sensitivity of this assay is 10 copies FIV per $\mu$ g of DNA [32]. Reaction mixtures containing $2 \times$ SYBR-Green master mix (Qiagen, Valencia, CA), $0.5 \mu \mathrm{M}$ primers, and 2-5 $\mu \mathrm{l}$ of each DNA sample were amplified in a 96-well plate (ABgene, Rochester, NY) using the Mx3000 (Stratagene, La Jolla, CA) and the following PCR conditions: $15 \mathrm{~min}$ at $94^{\circ} \mathrm{C}$ then 40 cycles of 30 seconds at $94^{\circ} \mathrm{C}$; 1 minute at $60^{\circ} \mathrm{C}$, and 30 seconds at $72^{\circ} \mathrm{C}$, followed by one cycle of 1 minute at $95^{\circ} \mathrm{C}$ and 30 seconds at $55^{\circ} \mathrm{C}$. Standard curves were generated for primer pairs using serial dilutions of the following plasmids: pCR2.1-GAPDH and pCR1-gag [31].

\section{Reverse transcriptase RT-PCR}

RNA was extracted from $200 \mu \mathrm{l}$ of plasma using High Pure Viral RNA Kit (Roche, Indianapolis, IN). Reverse transcription RT-PCR was performed in triplicate wells of a 96-well plate (ABgene, Rochester, NY) as one step RT-PCR in $25 \mu$ l containing 2-3 $\mu$ l of purified RNA, 0.5 $\mu \mathrm{M}$ QuantiTect RT Mix, $2 \times$ SYBR-Green master mix (Qiagen, Valencia, CA), and $0.5 \mu \mathrm{M}$ primers. Following 30 minutes at $50^{\circ} \mathrm{C}$ for reverse transcription, program conditions were as described above for RT-PCR. The detection limit of this assay is $\leq 10$ copies per $50 \mu \mathrm{l}$ of plasma and is similar to the findings of others [33].

\section{Flow cytometric analysis}

Absolute lymphocyte counts were calculated using an automated white blood cell count (VetSCAN HMT,
Abaxis, Union City, CA) and manual differential. T-cell subsets were analyzed by FACS Calibur (Becton Dickinson, San Jose, CA) as previously described $[29,30]$.

\section{Lymphoproliferation}

Lymphoproliferation was assayed in PBMC prior to exposure and in PBMC and tissue lymphocytes at 12 week post exposure $(\mathrm{PE})$. Cells $\left(1 \times 10^{5}\right)$ were incubated in triplicate in one of four conditions: lymphocyte media alone, $5 \mu \mathrm{g} / \mathrm{ml}$ of concanavalin A (Con A), irradiated cells as a mixed lymphocyte reaction (MLR), or whole cell lysate (WCL) at $37^{\circ} \mathrm{C}, 5 \% \mathrm{CO}_{2}$ for 4 days [34]. Irradiated cells and whole cell lysate were obtained from male donor (male), the cat's own PBMC (self), or the cells used for cell-associated FIV challenge (Mya-1). Irradiated cells for the MLR were obtained by irradiating cells in a T-25 flask or 6 well plates at a final concentration of $1 \times 10^{6} / \mathrm{mL}$ in lymphocyte media for 85 minutes @ 7500 rad in a Gammacell 40, cs-137 irradiator. Whole cell lysate (WCL) was prepared by sonicating the cells for 1 minute/5 mL @ 22 $\mu \mathrm{M}$ amplitude. Protein content was quantified using the Bradford reagent. Wells were pulsed with $1 \mu \mathrm{Ci}$ /well of tritiated thymidine (MP Biomedicals Corp., Irvine, CA) for $18 \mathrm{hrs}$ and then harvested using a FilterMate Cell Harvester (PerkinElmer Life Sciences, Downers Grove, IL). Uptake was quantified as counts per minute (CPM) using a MicroBeta Jet Liquid Scintillation and Luminescence counter (Wallac, Turku, Finland). Triplicates were averaged and the proliferation index (PI) was calculated: (Ave $\mathrm{CPM}$ at particular time point/Ave background CPM at same time point)/(Ave. CPM at pre/Ave background $\mathrm{CPM}$ at pre) $\times 100$. Pre exposure data was normalized to $100 \%$ for each animal and data presented as change from baseline.

\section{ELISA}

Serum antibody against FIV p24Gag was detected by adding serial dilutions of serum to microtiter plates (Immulon $2 \mathrm{HB}$, Dynex Technologies Inc., Chantilly, VA) coated with $0.1 \mu \mathrm{g} /$ well $\mathrm{p} 24 \mathrm{Gag}$ fusion protein as previously described [35]. Titers were expressed as the inverse of the highest dilution that produced an $\mathrm{OD} \geq 0.1$ and $\geq$ 3 -fold the OD of the animal's pre-study sample.

\section{Statistical analyses}

Flow phenotyping results were analyzed using analysis of covariance for PBMC and multivariate analysis of variance for tissue samples with separate models for each Tcell subset. For PBMC, differences between the Heterologous and Media groups were tested with the baseline percentage of the T-cell subset included as a covariate. For tissue sample results, the endpoints were the percentages of the T-cell subset in each of the five tissue sources (PLN, MLN, ILN, IEL, and LPL). Separate residual vari- 
ances were estimated for each tissue source. Contrasts within the model evaluated differences separately between Heterologous and Media groups for each type of tissue.

For MLR and WCL analyses, the endpoint was a cell PI measuring change from baseline. Linear mixed models were used to analyze differences in mean cell PI between the treatment groups and between antigen types (self, male, Mya-1). Also, for the post-challenge model, the challenge types (cell-free, cell-associated) were compared. PBMC models included a covariate for the baseline CPM ratio and a random subject effect. Tissue sample models were multivariate and estimated separate residual variances and random subject effects for each tissue type. Log-transformed PI values were used in the analyses in order to correct for skewness. All statistical tests were evaluated at the two-sided alpha $=.05$ significance level. Analyses were performed using $\mathrm{SAS}^{\circ}$ version 9.2 (The SAS Institute, Cary, NC).

Viral loads were used to calculate the arithmetic mean for different treatment groups and then compared using a Student's t-test with differences at $\mathrm{p}<0.05$ regarded as significant.

\section{Results}

Mucosal exposure to heterologous cells induces systemic and mucosal lymphocyte phenotype shifts

To determine whether repeated mucosal exposure to heterologous cells resulted in shifts of $\mathrm{T}$ cell subsets and activation status, blood and lymphoid tissues were examined by flow cytometry. No changes were detected in the total percentage of $\mathrm{CD} 4+$ or CD8+ $\mathrm{T}$ cells in the blood and lymphoid tissue (data not shown). L-selectin (CD62L) was examined as a marker primarily found on naïve lymphocytes as well as some central memory T cells [36-39]. Loss of L-selectin expression has previously been shown to correlate with FIV antiviral activity [40]. Following repeated mucosal exposure to heterologous cells, the percentage of $\mathrm{CD} 4+\mathrm{T}$ cells expressing $\mathrm{L}$-selectin were increased in the gut tissue, IEL $(\mathrm{p}=0.028)$ and decreased in iliac lymph node $(\mathrm{p}=0.0031)$ (Fig 1a). CD8+ T cells expressing L-selectin were increased in the blood $(\mathrm{p}=$ 0.033 ) and the gut tissue (IEL, $\mathrm{p}=0.0008$ ) but were decreased in the lymph nodes (ILN, $\mathrm{p}<0.0001 ;$ MLN, $\mathrm{p}=$ 0.024) (Fig 1b)

As is seen in other species, feline Tregs are predominantly CD4+CD25+ cells; and FoxP3 expression has recently been shown to correlate with dual CD4 and CD25 expression by lymphocytes [41]. Following repeated mucosal exposure to heterologous cells, the percentage of $\mathrm{CD} 4+\mathrm{CD} 25+\mathrm{T}$-cells was significantly decreased in the iliac $L N(p=0.0002)$, popliteal $L N(p=$
A.

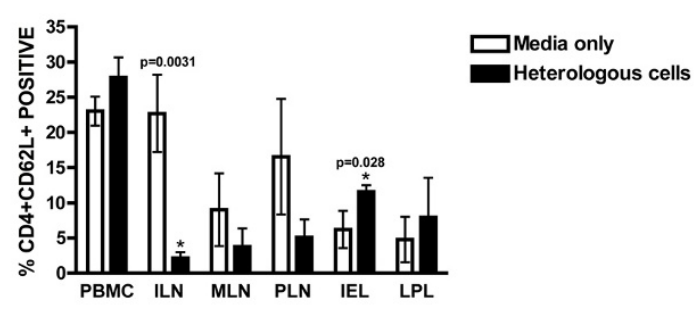

B.

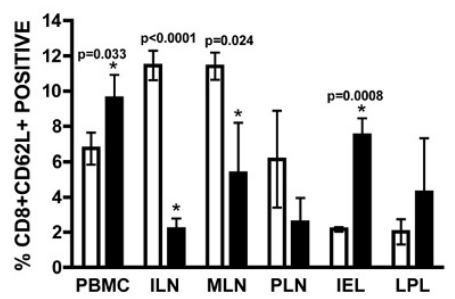

C.

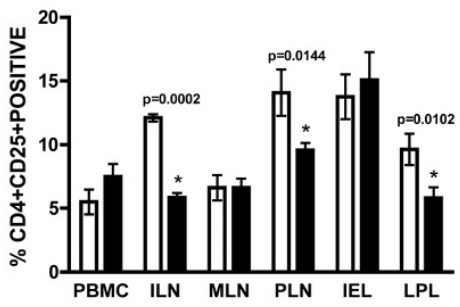

Figure 1 Percentage of (a) CD4+, and (b) CD8+ cells expressing Lselectin; and (c) CD4+25+ cells. Data present comparison of these cells in various tissues between media and heterologous cell exposed subjects Data presented as arithmetic mean, SD. * Statistically significant $(p<0.05)$ between Media and Heterologous groups for that tissue.

$0.0144)$, and intestinal LPL $(\mathrm{p}=0.0102)$ while no changes were noted in blood, mesenteric LN, or intestinal IEL (Fig 1c).

\section{Mucosal exposure to heterologous cells induces} lymphoproliferative responses against heterologous cells Exposure to heterologous cells for 12 weeks induced a MLR response against male and/or Mya-1 irradiated cells in multiple mucosal and systemic sites. Significant responses against male cells were detected in lymphocytes from the ILN, MLN, and LPL (ILN, p = 0.012; MLN, $\mathrm{p}=0.002$; LPL, $\mathrm{p}=0.01$ ) while significant responses against Mya-1 cells were only detected in the lymph nodes (ILN, $\mathrm{p}=0.008$; MLN, $\mathrm{p}=0.003$; PLN, $\mathrm{p}=0.03$ ) (Fig 2). Consistent with the naïve (CD62L+) phenotype found in blood, a significant proliferative response was not detected in PBMC (data not shown). Proliferation against whole cell lysate (WCL) of male cells only was detected in the ILN ( $p=0.004$, data not shown). Significant proliferation to WCL was not detected elsewhere. 
A.

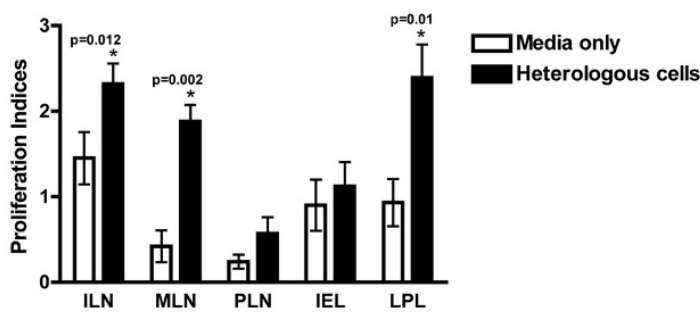

B.

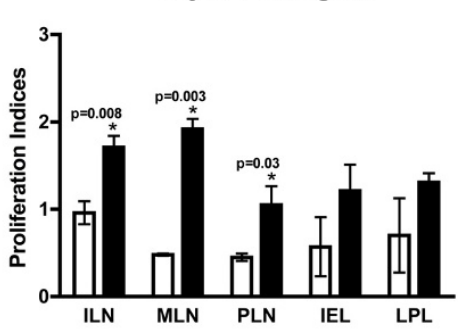

Figure 2 Mixed lymphocyte response against (a) male and (b) Mya-1 T cells in lymph nodes and gut. The data represent response after 12-weeks of repeated mucosal exposure to heterologous cells or media alone. Data are presented as arithmetic mean, SD cell proliferation index measuring change from baseline. * Statistically significant ( $p$ $<0.05$ ) between Media and Heterologous groups for that tissue.

Provirus burden is reduced following cell-associated mucosal challenge after previous exposure to heterologous cells

After repeated exposure to either media or heterologous cells, cats were vaginally challenged with cell-associated or cell-free FIV and viral load was measured after 12 weeks. FIV-RNA was consistently detected in the plasma of all cats challenged with FIV (Table 1 \&2) and was similar in animals challenged with cell-associated (Table 1) or cell-free FIV (Table 2). Provirus was detected in all animals but in cats challenged with cell-free FIV, copy numbers were lower, were not detected in all tissues, and there were no significant differences detected between the Media and Heterologous treatments (Table 2).

In contrast, in cats challenged with cell-associated virus, PBMC and tissue proviral burdens were approximately a log lower in animals previously exposed to heterologous cells (Fig 3) as compared to media controls. The same trend of reduced viral load was detected in blood samples taken 8 weeks post challenge (data not shown).

There was no detectable response to the p24Gag fusion protein after exposure to heterologous cells (or media) and prior to challenge. Antibody response was only detected after viral challenge. IgG against p24 was readily detected in all cats infected with cell-associated FIV (Table 1 ) but was undetectable $(n=4)$ or minimal (titer of $100-200 \mathrm{n}=3$ ) in the majority of cell-free challenged cats (Table 2).

\section{Discussion}

This study was designed to mimic what might occur in women exposed to multiple sexual partners and determine whether prior mucosal exposure to heterologous cells could alter lentiviral transmission or disease. In the study described here, cats repeatedly exposed to heterologous cells had reduced proviral burden when compared to cats receiving media alone following mucosal challenge with cell-associated but not cell-free FIV. While the final numbers of animals in each challenge group were relatively small $(n=4)$, we and others have demonstrated relevant challenge findings in the FIV and SIV animal models with final group sizes in this range [42-44]. In addition, cats mucosally exposed to heterologous cells had shifts in lymphocyte activation as well as proliferation against cellular antigens, including cells (Mya-1) that they had not been previously exposed to. This suggests that FIV infection was modulated by responses against the infected cells, not simply FIV, as no differences were seen between the groups following challenge with cellfree FIV.

Mucosal exposure to heterologous cells resulted in a reduced percentage of L-selectin positive in the LNs with a concurrent expansion of L-selectin positive cells in the blood and gut. L-selectin (CD62L) is expressed on naive CD4+ T cells as well as a small subset of memory $\mathrm{T}$ cells and facilitates immune surveillance by enabling the cells to recirculate and compartmentalize between blood and lymph node [36-39]. FIV and HIV infections are associated with progressive immune dysfunction with reduced capacity to respond due to poor response to recall antigens [45-48]. L-selectin expression may thus affect HIV-1 pathogenesis by altering the ability to recall antigens. It may also play a role in HIV-1 pathogenesis by enhancing virus transmission to CD4+ T lymphocytes [49] possibly due to enhanced expression of surface CXCR4 in lymphocytes through L-selectin signaling have been suggested [50]. Hence, changes in L-selectin expressed cells after mucosal exposure may be responsible for the observed alteration of susceptibility to FIV infection.

Changes in L-selectin expression after mucosal exposure were most evident in the iliac LN $(C D 4+62 \mathrm{~L}+, \mathrm{p}=$ 0.0031; CD8+62L+, p $<0.0001)$ and IEL populations $(\mathrm{CD} 4+62 \mathrm{~L}+, \mathrm{p}=0.028 ; \mathrm{CD} 8+62 \mathrm{~L}+, \mathrm{p}=0.0008)$. The marked ILN changes are likely attributable to the site of exposure as the ILN drains the cervicovaginal mucosa. Previously, we have shown that the ILN and IEL lymphocyte populations are uniquely altered in chronic FIV infection [51] indicating that the immune function and 


\begin{tabular}{|c|c|c|c|c|c|c|c|c|}
\hline \multirow{2}{*}{$\begin{array}{c}\text { Cat ID } \\
\text { Media only }\end{array}$} & \multicolumn{6}{|c|}{ gag copy/million GAPDH } & \multirow{2}{*}{$\begin{array}{c}\text { gag copy } / \mathrm{mL} \\
\text { PLASMA }\end{array}$} & \multirow{2}{*}{$\begin{array}{c}\text { Anti-FIV p24 IgG dilution } \\
\text { SERUM }\end{array}$} \\
\hline & PBMC & ILN & MLN & PLN & IEL & LPL & & \\
\hline AMX1 & 15585 & 9135 & 4899 & 7366 & 1072 & 68 & 73 & 12800 \\
\hline AMY5 & 83572 & 37693 & 29756 & 65000 & 3062 & 538 & 69 & 102400 \\
\hline ANG5 & 29819 & 21413 & 10079 & 34634 & 3700 & 173 & 63 & 6400 \\
\hline ANE5 & 2313 & 6737 & 2683 & 6100 & 1815 & NA & 61 & 400 \\
\hline MEAN & 32822 & 18745 & 11854 & 28275 & 2412 & 260 & 67 & 30500 \\
\hline \multicolumn{9}{|c|}{ Heterologous cells } \\
\hline ANZ4 & 1265 & 2261 & 116 & 887 & 0 & 5 & 44 & 6400 \\
\hline QNY5 & 2251 & 9563 & 2255 & 9225 & 1603 & NA & 83 & 800 \\
\hline AMY6 & 20177 & 22633 & 7848 & 20530 & 3796 & 5 & 70 & 12800 \\
\hline AMW5 & 5477 & 11740 & 3434 & 9716 & 0 & 44 & 26 & 6400 \\
\hline MEAN & 7293 & 11549 & 3413 & 10089 & 1350 & 18 & 56 & 6600 \\
\hline
\end{tabular}

interactions at these sites should be further investigated in multiple model systems.

In the LN, the shift to an activated phenotype occurred concurrently with functional lymphocyte activation as measured by proliferation whereas the LPL response was enhanced without a detectable expansion of activated cells. This may be related to the high percentage of activated cells normally present in the gut [52]. Interestingly, the MLR response that developed following exposure to heterologous cells was also cross-reactive against cells that the animals had not been exposed to, namely the Mya-1 cell line. This cross reactive immune response was likely responsible for the decrease in viral burden seen following subsequent challenge with FIV infected Mya-1 cells but not CF FIV.

The shift towards an activated phenotype and concurrent proliferative response was also associated with a reduction in the percentage of $\mathrm{CD} 4+\mathrm{CD} 25+$ cells in the $\operatorname{ILN}(\mathrm{p}=0.0002)$, PLN ( $\mathrm{p}=0.0144)$, and LPL $(\mathrm{p}=0.0102)$. Feline CD4+CD25+ cells have been previously shown to have regulatory activity ex vivo and in vitro [53]. FoxP3, a marker of Treg activity, increases in CD4+CD25+ T cells following FIV infection $[41,54]$. While we did not measure regulatory function and FoxP3 reagents were not

Table 2: Cell-free FIV challenge summary

\begin{tabular}{|c|c|c|c|c|c|c|c|c|}
\hline \multirow{2}{*}{\begin{tabular}{c|} 
Cat ID \\
Media only
\end{tabular}} & \multicolumn{6}{|c|}{ gag copy/million GAPDH } & \multirow{2}{*}{$\begin{array}{c}\text { gag copy/mL } \\
\text { PLASMA }\end{array}$} & \multirow{2}{*}{$\begin{array}{c}\text { Anti-FIV p24 IgG dilution } \\
\text { SERUM }\end{array}$} \\
\hline & PBMC & ILN & MLN & PLN & IEL & LPL & & \\
\hline IMO4 & 1299 & 1495 & 0 & 762 & 0 & 0 & 51 & 200 \\
\hline QNV2 & 1674 & 7905 & 0 & 1544 & 0 & 0 & 50 & 0 \\
\hline ANC6 & 1579 & 3676 & 0 & 1153 & 0 & 0 & 62 & 0 \\
\hline AMW6 & 2035 & 2554 & 0 & 973 & 0 & 0 & 48 & 200 \\
\hline MEAN & 1647 & 3907 & 0 & 1108 & 0 & 0 & 53 & 100 \\
\hline \multicolumn{9}{|c|}{ Heterologous cells } \\
\hline AMY3 & 1877 & 2927 & 543 & 2595 & 285 & 3 & 50 & 6400 \\
\hline AMW3 & 1372 & 4514 & 0 & 1694 & 0 & 0 & 56 & 0 \\
\hline AMX3 & 1554 & 3767 & 0 & NA & NA & 0 & 51 & 100 \\
\hline QNU6 & 1606 & 2551 & 0 & NA & 886 & 0 & 25 & 0 \\
\hline MEAN & 1602 & 3440 & 136 & 2144 & 390 & 1 & 45 & 1625 \\
\hline
\end{tabular}




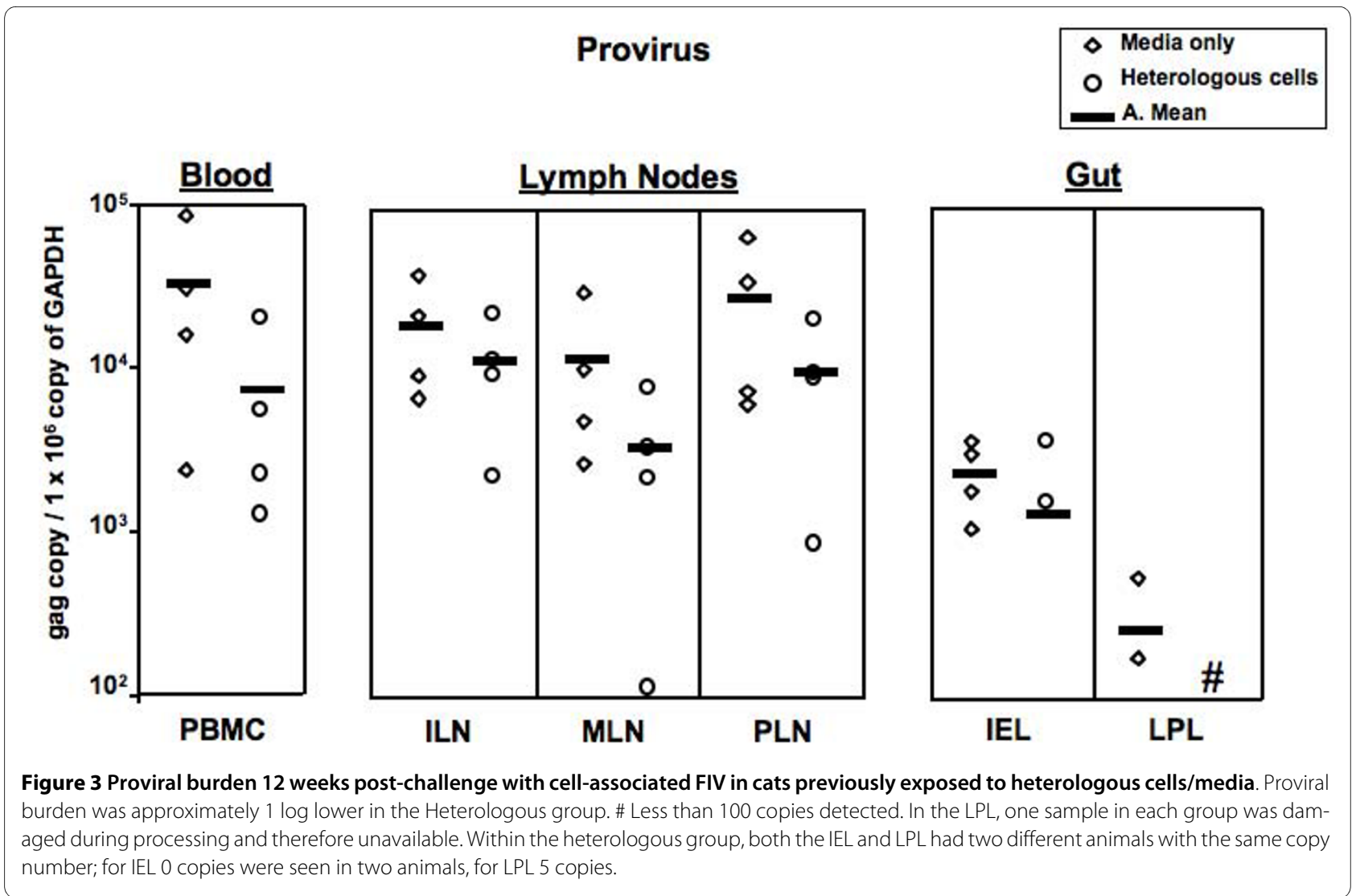

available at the time of this study, the data suggests that a reduction of the number of T-regulatory cells within the environment was associated with the development of an effector immune response. Tregs may play a crucial role in immunopathogenesis of many viral infections including herpes simplex virus (HSV), hepatitis $\mathrm{C}$ virus (HCV), Friend virus and lentiviruses including FIV [53-58]. These studies suggest that activation of Tregs following viral infection leads to suppression of CD4+ and CD8+ effector responses resulting in decreased viral clearance and consequently establishment of infection. In-vitro studies suggest that Treg cells from HIV-infected subjects suppress the effector function of CD8+ antigen-specific HIV gag responses $[59,60]$. Though mechanisms involved in suppression of infection by Treg depletion remain unclear, few studies have suggested granzyme, CTLA-4, and tumor growth factor (TGF-beta), chemokine and cytokine regulation [61-63]. Previous allograft studies suggest the role of Treg cells in inhibiting alloimmune responses $[64,65]$.

In contrast to the strong MLR response detected against whole cells at multiple sites, we did not find significant proliferation against cell lysate after heterologous cell exposure except in the ILN. This response was likely confined to the draining lymph node due to rapid degradation however a unique response against intracellular antigens cannot be excluded. Taken together, these data suggest that the immune activation and relative protection induced by exposure to heterologous cells was due to responses against cell surface antigens versus intracellular antigens and is consistent with findings that intact stimulating cells are required for efficacious production of antiHIV activity [66]. Whether this is due to conformational interactions, interaction with secondary molecules, or a combination has relevance for vaccine and small molecule therapy and remains an area for investigation.

Although neutralizing antibodies were not measured in this study, previous reports support the potential for a protective role by the humoral arm of the immune system. Vaccination of macaques with uninfected human cells were found to be protected against SIV grown in the same cell type and protection was correlated with the detection of anti-HLA class I antibodies [5]. Because viral gp120 and HLA share a degree of homology [67] it has been hypothesized that anti-HLA antibodies may neutralize free virions by binding to HLA or gp120 on the viral envelope leading to cross-reactive protection. Given recent detection of antibodies against cell line antigens in cats vaccinated with commercially available vaccines generated in this cell line, the contribution of cross-reactive humoral responses is clearly worth further investigation [68]. 
In this study, cats previously exposed to heterologous cells and then challenged with cell-associated FIV had lower tissue proviral burdens than those had been previously only exposed to media. This was not true for cellfree FIV, a finding also supported by a recent study [69]. Taken together; these studies strongly suggest that intact cellular proteins are critical for induction of protective immune responses against infected cells. As cell-associated virus appears to have an important role in HIV sexual transmission [70-73], our findings are encouraging as exposure to heterologous male lymphocytes induced cross-reactive proliferation against the challenge inoculum cells suggesting that cross reactivity plays a significant role in allo-induced antiviral activity. An additional control could have been to examine the effect of mucosal exposure to the challenge cells (Mya-1). It is reasonable to speculate that prior exposure to uninfected Mya-1 cells would induce the strongest protection to FIV-infected Mya-1 cells, however it is also possible that exposure to a uniform cell line may have induced immune responses that varied markedly from what would be seen following exposure to a heterogeneous 'normal' lymphocyte population as we examined in this study.

Under natural conditions, biting appears to be the most efficient mode of FIV transmission. Virus is easily isolated from the saliva of infected cats and both experimental and epidemiological studies suggest that a single bite exposure is sufficient to transmit the virus from an infected to a naive cat [74]. Infectious FIV is present in genital secretions from naturally and experimentally infected male cats [75-77]. Replication-competent FIV is found in both the cell-free fraction and cell- associated fraction of semen and can be transmitted to cats by a single uterine artificial insemination [75,77].

As an animal model, mucosal transmission of FIV has been developed extensively. FIV transmission mimics the diversity apparent in $\mathrm{HIV}-1$ vaginal transmission and virus strains representing at least three subtypes of FIV can be transmitted across the vaginal, rectal, or oral mucosa by cell-associated as well as cell-free virus $[34,78$ 83 ] similar to reported previously $[84,85,72]$, mucosal exposure to cell-associated FIV resulted in greater virus burden than did exposure to cell-free FIV, particularly in the gut. This could be due to dose effect. However, there is no gold standard to directly correlate in vitro cell-free and cell-associated titrations with each other or to predict in vivo outcomes. In addition, a recent study suggests that mucosal dose alone is not predictive of infection outcome [86].

While exposure to heterologous cells did not provide complete protection, the log reduction in proviral burden after cell-associated challenge is similar to the reduction in virus burden reported in vaccine studies [2-8]. Because early viral set point and higher virus burden predict a more rapid progression of HIV infection [87,88], containing the virus early on appears to alter the downstream progression to disease that can have significant effects on patient health as well as potential transmission to others. The results reported here are particularly significant given the high-dose challenge used in this study. Although high-dose challenges are commonly used in animal model studies, lower doses more likely mimic what is seen in HIV-1 exposure, particularly sexual exposure. As mucosal administration of low-dose cell-associated FIV results in non-progressive infection (Burkhard unpublished data) or viral latency [28], further reduction of infection by a log under low-dose exposure circumstances may increase the threshold for infection resulting in local or 'silent' infection as has been reported in certain high-risk cohorts [89-92].

\section{Conclusion}

Multiple mechanisms have been proposed for the lack of infection in HIV-1 exposed but seronegative individuals including viral determinants of infection, low-level HIV-1 cellular and humoral immune responses, and genetic variation. However, the phenomenon remains poorly understood. Several SIV and FIV vaccine studies, as well as human epidemiologic data, suggest that alloimmune responses may be associated with protection against lentiviral infection [2-8]. We examined the role of vaginal exposure to heterologous cells on lentiviral infection by using the FIV model of mucosal transmission. We found that repeated exposure of the mucosa to heterologous cells led to functional and phenotypic activation of immune system. This suggests that the threshold for mucosal infection by infected cells or the early pathogenesis can be modulated by immune responses against heterologous cells. This is further supported by the absence of differences in viral burden between those challenged with CF virus. Overall, our data suggests that mucosal exposure to non-viral antigens may induce cross-reactive immune responses that can reduce virus burden. While these may not be completely protective, the ability to reduce early viral set points has significant implications for further transmission and disease progression and hence may provide additional strategies for therapy and vaccination. Our findings support a need to reexamine the role that immune responses against heterologous and allogeneic cells may play in HIV-1 transmission, early infection, viral dissemination, and progression to disease.

\section{Competing interests \\ The authors declare that they have no competing interests.}

\section{Authors' contributions}

SBK, SEL and MJB were responsible for the design of the study. SBK and MJB were responsible for the draft of the manuscript. SBK performed most of experiments. SEL performed flow cytometry experiments. BA helped in isolation of 
IEL, IPL and provided FIV viral stocks. KP performed statistical analysis. All authors read and approved the final manuscript.

\section{Acknowledgements}

This work was supported by NIH/NIAID R21 Al065260. We are grateful to Abby Monnin and Colleen Morrill for organizational, sampling, and study assistance.

\section{Author Details}

'Department of Veterinary Biosciences, The Ohio State University, Columbus, Ohio, USA, 2Center for Retrovirus Research, The Ohio State University, Columbus, Ohio, USA, ${ }^{3}$ Center for Microbial Interface Biology, The Ohio State University, Columbus, Ohio, USA and ${ }^{4}$ Center for Biostatistics, The Ohio State University, Columbus, Ohio, USA

Received: 15 December 2009 Accepted: 28 May 2010

Published: 28 May 2010

\section{References}

1. Shearer GM, Clerici M, Dalgleish A: Alloimmunization as an AIDS vaccine? Science 1993, 262:161-162

2. Arthur LO, Bess JW Jr, Urban RG, Strominger JL, Morton WR, Mann DL Henderson LE, Benveniste RE: Macaques immunized with HLA-DR are protected from challenge with simian immunodeficiency virus. J Virol 1995, 69:3117-3124

3. Stott EJ, Chan WL, Mills KH, Page M, Taffs F, Cranage M, Greenaway P, Kitchin P: Preliminary report: protection of cynomolgus macaques against simian immunodeficiency virus by fixed infected-cell vaccine. Lancet 1990, 336:1538-1541.

4. Langlois AJ, Weinhold KJ, Matthews TJ, Greenberg ML, Bolognesi DP Detection of anti-human cell antibodies in sera from macaques immunized with whole inactivated virus. AIDS Res Hum Retroviruses 1992, 8:1641-1652.

5. Chan WL, Rodgers A, Hancock RD, Taffs F, Kitchin P, Farrar G, Liew FY: Protection in simian immunodeficiency virus-vaccinated monkeys correlates with anti-HLA class I antibody response. J Exp Med 1992, 176:1203-1207

6. Karlas JA, Siebelink KH, vPeer MA, Huisman W, Rimmelzwaan GF, Osterhaus AD: Accelerated viraemia in cats vaccinated with fixed autologous FIV-infected cells. Vet Immunol Immunopathol 1998 65:353-365

7. Karlas JA, Siebelink KH, Peer MA, Huisman W, Cuisinier AM, Rimmelzwaan GF, Osterhaus AD: Vaccination with experimental feline immunodeficiency virus vaccines, based on autologous infected cells, elicits enhancement of homologous challenge infection. J Gen Virol 1999, 80(Pt 3):761-765.

8. Giannecchini S, Isola P, Sichi O, Matteucci D, Pistello M, Zaccaro L, Del Mauro D, Bendinelli M: AIDS vaccination studies using an ex vivo feline immunodeficiency virus model: failure to protect and possible enhancement of challenge infection by four cell-based vaccines prepared with autologous lymphoblasts. J Virol 2002, 76:6882-6892.

9. Chan WL, Rodgers A, Grief C, Almond N, Ellis S, Flanagan B, Silvera P, Bootman J, Stott J, Kent K, Bomford R: Immunization with class I human histocompatibility leukocyte antigen can protect macaques against challenge infection with SIVmac-32H. Aids 1995, 9:223-228.

10. Stott EJ: Anti-cell antibody in macaques. Nature 1991, 353:393.

11. Fowke KR, Nagelkerke NJ, Kimani J, Simonsen JN, Anzala AO, Bwayo JJ, MacDonald KS, Ngugi EN, Plummer FA: Resistance to HIV-1 infection among persistently seronegative prostitutes in Nairobi, Kenya. Lancet 1996, 348:1347-1351.

12. Shearer GM, Pinto LA, Clerici M: Alloimmunization for immune-based therapy and vaccine design against HIV/AIDS. Immunol Today 1999 20:66-71

13. Lehner T, Shearer GM, Hackett CJ, Schultz A, Sharma OK Alloimmunization as a strategy for vaccine design against HIV/AIDS. AIDS Res Hum Retroviruses 2000, 16:309-313.

14. Spruth M, Stoiber H, Kacani L, Schonitzer D, Dierich MP: Neutralization of HIV type 1 by alloimmune sera derived from polytransfused patients. AIDS Res Hum Retroviruses 1999, 15:533-543.

15. Pinto LA, Sharpe S, Cohen DI, Shearer GM: Alloantigen-stimulated antiHIV activity. Blood 1998, 92:3346-3354.

16. Wang $Y$, Tao L, Mitchell E, Bravery C, Berlingieri $P$, Armstrong $P$, Vaughan $R$, Underwood J, Lehner T: Allo-immunization elicits CD8+ T cell-derived chemokines, HIV suppressor factors and resistance to HIV infection in women. Nat Med 1999, 5:1004-1009.

17. Sriwanthana B, Hodge T, Mastro TD, Dezzutti CS, Bond K, Stephens HA Kostrikis LG, Limpakarnjanarat K, Young NL, Qari SH, Lal RB, Chandanayingyong D, McNicholl JM: HIV-specific cytotoxic T lymphocytes, HLA-A11, and chemokine-related factors may act synergistically to determine HIV resistance in CCR5 delta32-negative female sex workers in Chiang Rai, northern Thailand. AIDS Res Hum Retroviruses 2001, 17:719-734.

18. Plummer FA, Ball TB, Kimani J, Fowke KR: Resistance to HIV-1 infection among highly exposed sex workers in Nairobi: what mediates protection and why does it develop? Immunol Lett 1999, 66:27-34.

19. MacDonald KS, Fowke KR, Kimani J, Dunand VA, Nagelkerke NJ, Ball TB, Oyugi J, Njagi E, Gaur LK, Brunham RC, Wade J, Luscher MA, Krausa P, Rowland-Jones S, Ngugi E, Bwayo JJ, Plummer FA: Influence of HLA supertypes on susceptibility and resistance to human immunodeficiency virus type 1 infection. J Infect Dis 2000, 181:1581-1589.

20. MacDonald KS, Embree J, Njenga S, Nagelkerke NJ, Ngatia I, Mohammed Z, Barber BH, Ndinya-Achola J, Bwayo J, Plummer FA: Mother-child class I HLA concordance increases perinatal human immunodeficiency virus type 1 transmission. J Infect Dis 1998, 177:551-556.

21. Quayle AJ, Fidel P Jr, Rosenberg ES: Sex, alloimmunisation, and susceptibility to HIV infection. Lancet 2004, 363:503-504

22. Krieger J, Coombs R, Collier A, Ross S, Chaloupka K, Cummings D, Murphy $V$, Corey L: Recovery of human immunodeficiency virus type 1 from semen: minimal impact of stage of infection and current antiviral chemotherapy. Infect Dis J 1991, 163:386-388.

23. Plummer F, Simonsen J, Cameron D, Ndinya-Achola J, Kreiss J, Gakinya M, Waiyaki $P$, Cheang M, Piot $P$, Ronald A: Cofactors in male-female sexual transmission of human immunodeficiency virus type 1. J Infect Dis 1991, 163:233-239.

24. Spinillo A, Zara F, De Santolo A, Brerra R, Maserati R, Romero E, Filice G: Quantitative assessment of cell-associated and cell-free virus in cervicovaginal samples of HIV-1-infected women. Clin Microbiol Infect 1999, 5:605-611.

25. WHO/UNAIDS: AIDS Epidemic Update. Joint United Nations Programme on HIV/AIDS 20082008

26. Quayle AJ, Xu C, Mayer KH, Anderson DJ: T Lymphocytes and Macrophages, but Not Motile Spermatozoa, Are a Significant Source of Human Immunodeficiency Virus in Semen. The Journal of Infectious Diseases 1997, 176:960-968.

27. Jeng C, English R, Childers T, Tompkins M, Tompkins W: Evidence for CD8+ antiviral activity in cats infected with feline immunodeficiency virus. J Virol 1996, 70:2474-2480.

28. Assogba BD, Leavell S, Porter K, Burkhard MJ: Mucosal administration of low-dose cell-associated feline immunodeficiency virus promotes viral latency. J Infect Dis 2007, 195:1184-1188.

29. Burkhard MJ, Valenski L, Leavell S, Dean GA, Tompkins WA: Evaluation of FIV protein-expressing VEE-replicon vaccine vectors in cats. Vaccine 2002, 21:258-268.

30. Howard KE, Fisher IL, Dean GA, Jo Burkhard M: Methodology for isolation and phenotypic characterization of feline small intestinal leukocytes. $J$ Immunol Methods 2005, 302:36-53.

31. Stevens R, Howard KE, Nordone S, Burkhard M, Dean GA: Oral immunization with recombinant listeria monocytogenes controls virus load after vaginal challenge with feline immunodeficiency virus. J Virol 2004, 78:8210-8218.

32. Stevens R, Howard K, Nordone S, Burkhard M, Dean G: Oral immunization with recombinant listeria monocytogenes controls virus load after vaginal challenge with feline immunodeficiency virus. J Virol 2004, 78:8210-8218.

33. Howard K, Reckling S, Egan E, Dean G: Acute mucosal pathogenesis of feline immunodeficiency virus is independent of viral dose in vaginally infected cats. Retrovirology 2010, 7:2.

34. Burkhard MJ, Obert LA, O'Neil LL, Diehl LJ, Hoover EA: Mucosal transmission of cell-associated and cell-free feline immunodeficiency virus. AIDS Res Hum Retroviruses 1997, 13:347-355.

35. Reid G, Rigby M, McDonald M, Hosie M, Neil J, Jarrett O: Immunodiagnosis of feline immunodeficiency virus infection using recombinant viral p17 and p24. Aids 1991, 5:1477-1483. 
36. Catalina MD, Carroll MC, Arizpe H, Takashima A, Estess P, Siegelman MH: The route of antigen entry determines the requirement for L-selectin during immune responses. J Exp Med 1996, 184:2341-2351.

37. Butcher EC, Picker LJ: Lymphocyte homing and homeostasis. Science 1996, 272:60-66.

38. Hengel RL, Thaker V, Pavlick MV, Metcalf JA, Dennis G Jr, Yang J, Lempicki RA, Sereti I, Lane HC: Cutting Edge: L-Selectin (CD62L) Expression Distinguishes Small Resting Memory CD4+ T Cells That Preferentially Respond to Recall Antigen. JImmunol 2003, 170:28-32.

39. Sallusto F, Lenig D, Forster R, Lipp M, Lanzavecchia A: Two subsets of memory T lymphocytes with distinct homing potentials and effector functions. Nature 1999, 401:708-712.

40. Gebhard DH, Dow JL, Childers TA, Alvelo Jl, Tompkins MB, Tompkins WA: Progressive expansion of an L-selectin-negative CD8 cell with antifeline immunodeficiency virus (FIV) suppressor function in the circulation of FIV-infected cats. J Infect Dis 1999, 180:1503-1513.

41. Lankford S, Petty C, LaVoy A, Reckling S, Tompkins W, Dean GA: Cloning of feline FOXP3 and detection of expression in CD4+CD25+ regulatory $T$ cells. Veterinary immunology and immunopathology 2008, 122:159-166.

42. Willer DO, Guan Y, Luscher MA, Li B, Pilon R, Fournier J, Parenteau M, Wainberg MA, Sandstrom P, MacDonald KS: Multi-Low-Dose Mucosal Simian Immunodeficiency Virus SIVmac239 Challenge of Cynomolgus Macaques Immunized with "Hyperattenuated" SIV Constructs. J Virol 2010, 84:2304-2317

43. Bolton DL, Minang JT, Trivett MT, Song K, Tuscher JJ, Li Y, Piatak M Jr, O'Connor D, Lifson JD, Roederer M, Ohlen C: Trafficking, Persistence, and Activation State of Adoptively Transferred Allogeneic and Autologous Simian Immunodeficiency Virus-Specific CD8+ T Cell Clones during Acute and Chronic Infection of Rhesus Macaques. J Immunol 2010, 184:303-314.

44. Vagenas P, Williams VG, Piatak MJ, Bess JWJ, Lifson JD, Blanchard JL, Gettie A, Robbiani M: Tonsillar Application of AT-2 SIV Affords Partial Protection Against Rectal Challenge With SIVmac239. JAIDS Journal of Acquired Immune Deficiency Syndromes 2009, 52:433-442.

45. Tompkins MB, Tompkins WA: Lentivirus-induced immune dysregulation. Vet Immunol Immunopathol 2008, 123:45-55.

46. Hazenberg MD, Otto SA, van Benthem BH, Roos MT, Coutinho RA, Lange $J M$, Hamann Dr, Prins M, Miedema F: Persistent immune activation in HIV-1 infection is associated with progression to AIDS. Aids 2003 , 17:1881-1888

47. Davidson M, Rottman J, English R, Lappin M, Tompkins M: Feline immunodeficiency virus predisposes cats to acute generalized toxoplasmosis. Am J Pathol 1993, 143:1486-1497.

48. Dean GA, Bernales JA, Pedersen NC: Effect of feline immunodeficiency virus on cytokine response to Listeria monocytogenes in vivo. Veterinary immunology and immunopathology 1998, 65:125-138.

49. Thibault S, Tardif MR, Gilbert C, Tremblay MJ: Virus-associated host CD62L increases attachment of human immunodeficiency virus type 1 to endothelial cells and enhances trans infection of CD4+ T lymphocytes. J Gen Virol 2007, 88:2568-2573.

50. Ding Z, Issekutz TB, Downey GP, Waddell TK: L-selectin stimulation enhances functional expression of surface CXCR4 in lymphocytes: implications for cellular activation during adhesion and migration. Blood 2003, 101:4245-4252.

51. Howard KE, Burkhard MJ: FIV infection induces unique changes in phenotype and cellularity in the medial iliac lymph node and intestinal IEL. AIDS Res Hum Retroviruses 2007, 23:720-728.

52. James SP: Mucosal T-cell function. Gastroenterol Clin North Am 1991, 20:597-612.

53. Vahlenkamp TW, Tompkins MB, Tompkins WA: Feline immunodeficiency virus infection phenotypically and functionally activates immunosuppressive CD4+CD25+ T regulatory cells. J Immuno/ 2004, 172:4752-4761.

54. Mexas AM, Fogle JE, Tompkins WA, Tompkins MB: CD4+CD25+ regulatory $T$ cells are infected and activated during acute FIV infection. Vet Immunol Immunopathol 2008, 126:263-272.

55. Suvas S, Kumaraguru U, Pack CD, Lee S, Rouse BT: CD4+CD25+ T Cells Regulate Virus-specific Primary and Memory CD8+ T Cell Responses. The Journal of Experimental Medicine 2003, 198:889-901.

56. Baumforth KR, Birgersdotter A, Reynolds GM, Wei W, Kapatai G, Flavell JR, Kalk E, Piper K, Lee S, Machado L, Hadley K, Sundblad A, Sjoberg J, Bjorkholm M, Porwit AA, Yap LF, Teo S, Grundy RG, Young LS, Ernberg I,
Woodman CB, Murray PG: Expression of the Epstein-Barr Virus-Encoded Epstein-Barr Virus Nuclear Antigen 1 in Hodgkin's Lymphoma Cells Mediates Up-Regulation of CCL20 and the Migration of Regulatory T Cells. Am J Pathol 2008, 173:195-204

57. Robertson SJ, Messer RJ, Carmody AB, Hasenkrug KJ: In Vitro Suppression of CD8+ T Cell Function by Friend Virus-Induced Regulatory T Cells. J Immunol 2006, 176:3342-3349.

58. Boettler T, Spangenberg HC, Neumann-Haefelin C, Panther E, Urbani S, Ferrari C, Blum HE, von Weizsacker F, Thimme R: T Cells with a CD4+CD25+ Regulatory Phenotype Suppress In Vitro Proliferation of Virus-Specific CD8+ T Cells during Chronic Hepatitis C Virus Infection. J Virol 2005, 79:7860-7867.

59. Eggena MP, Barugahare B, Jones N, Okello M, Mutalya S, Kityo C, Mugyenyi P, Cao H: Depletion of Regulatory T Cells in HIV Infection Is Associated with Immune Activation. J Immunol 2005, 174:4407-4414.

60. Kinter AL, Horak R, Sion M, Riggin L, McNally J, Lin Y, Jackson R, O'shea A, Roby G, Kovacs C, Connors M, Migueles SA, Fauci AS: CD25+ regulatory T cells isolated from HIV-infected individuals suppress the cytolytic and nonlytic antiviral activity of HIV-specific CD8+ T cells in vitro. AIDS Res Hum Retroviruses 2007, 23:438-450.

61. von Boehmer $\mathrm{H}$ : Mechanisms of suppression by suppressor T cells. Nat Immunol 2005, 6:338-344.

62. Gondek DC, Lu LF, Quezada SA, Sakaguchi S, Noelle RJ: Cutting edge: contact-mediated suppression by $\mathrm{CD} 4+\mathrm{CD} 25+$ regulatory cells involves a granzyme B-dependent, perforin-independent mechanism. $\mathrm{J}$ Immunol 2005, 174:1783-1786.

63. Fogle JE, Mexas AM, Tompkins WA, Tompkins MB: CD4(+)CD25(+) T regulatory cells inhibit $C D 8(+)$ IFN-gamma production during acute and chronic FIV infection utilizing a membrane TGF-beta-dependent mechanism. AIDS Res Hum Retroviruses 2010, 26:201-216.

64. Sanchez-Fueyo A, Sandner S, Habicht A, Mariat C, Kenny J, Degauque N, Zheng XX, Strom TB, Turka LA, Sayegh MH: Specificity of CD4+CD25+ regulatory $T$ cell function in alloimmunity. J Immunol 2006, 176:329-334

65. Zang W, Lin M, Kalache S, Zhang N, Kruger B, Waaga-Gasser AM, Grimm M, Hancock W, Heeger P, Schroppel B, Murphy B: Inhibition of the Alloimmune Response through the Generation of Regulatory T Cells by a MHC Class II-Derived Peptide. J Immunol 2008, 181:7499-7506.

66. Grene E, Pinto LA, Cohen SS, Mac Trubey C, Trivett MT, Simonis TB, Liewehr DJ, Steinberg SM, Shearer GM: Generation of alloantigen-stimulated anti-human immunodeficiency virus activity is associated with HLAA*02 expression. J Infect Dis 2001, 183:409-416.

67. Habeshaw J, Hounsell E, Dalgleish A: Does the HIV envelope induce a chronic graft-versus-host-like disease? Immunol Today 1992, 13:207-210.

68. Whittemore JC, Hawley JR, Jensen WA, Lappin MR: Antibodies against Crandell Rees Feline Kidney (CRFK) Cell Line Antigens, -Enolase, and Annexin A2 in Vaccinated and CRFK Hyperinoculated Cats. Journal of Veterinary Internal Medicine 2010, 24:306-313.

69. Reggeti F, Bienzle D: Alloimmunity does not protect from challenge with the feline immunodeficiency virus. Vet Immunol Immunopathol 2008, 124:152-162.

70. Davidson JB, Douglas GC: Modulation of integrin function inhibits HIV transmission to epithelial cells and fertilization. J Reprod Immunol 1998, 41:271-290.

71. Krieger JN, Coombs RW, Collier AC, Ross SO, Chaloupka K, Cummings DK, Murphy VL, Corey L: Recovery of human immunodeficiency virus type 1 from semen: minimal impact of stage of infection and current antiviral chemotherapy. J Infect Dis 1991, 163:386-388.

72. Tindall B, Evans L, Cunningham P, McQueen P, Hurren L, Vasak E, Mooney J, Cooper DA: Identification of HIV-1 in semen following primary HIV-1 infection. Aids 1992, 6:949-952

73. Lewis DE, Yoffe B, Bosworth CG, Hollinger FB, Rich RR: Human immunodeficiency virus-induced pathology favored by cellular transmission and activation. Faseb J 1988, 2:251-255.

74. Yamamoto JK, Hansen H, Ho EW, Morishita TY, Okuda T, Sawa TR, Nakamura RM, Pedersen NC: Epidemiologic and clinical aspects of feline immunodeficiency virus infection in cats from the continental United States and Canada and possible mode of transmission. J Am Vet Med Assoc 1989, 194:213-220. 
75. Jordan H, Howard J, Sellon R, Wildt D, Tompkins W, Kennedy-Stoskopf S: Transmission of feline immunodeficiency virus in domestic cats via artificial insemination. J Virol 1996, 70:8224-8228.

76. Jordan HL, Howard J, Barr MC, Kennedy-Stoskopf S, Levy JK, Tompkins WA: Short Communication: Feline Immunodeficiency Virus Is Shed in Semen from Experimentally and Naturally Infected Cats. AIDS Research and Human Retroviruses 1998, 14:1087-1092.

77. Jordan HL, Liang Y, Hudson LC, Tompkins WA: Expression of feline immunodeficiency virus in semen during acute infection. Am J Vet Res 1999, 60:211-215.

78. Bucci JG, English RV, Jordan HL, Childers TA, Tompkins MB, Tompkins WA Mucosally transmitted feline immunodeficiency virus induces a CD8+ antiviral response that correlates with reduction of cell-associated virus. J Infect Dis 1998, 177:18-25.

79. Moench TR, Whaley KJ, Mandrell TD, Bishop BD, Witt CJ, Cone RA: The cat/ feline immunodeficiency virus model for transmucosal transmission of AIDS: nonoxynol-9 contraceptive jelly blocks transmission by an infected cell inoculum. Aids 1993, 7:797-802.

80. Bishop SA, Stokes CR, Gruffydd-Jones TJ, Whiting CV, Harbour DA: Vaginal and rectal infection of cats with feline immunodeficiency virus. Vet Microbiol 1996, 51:217-227.

81. O'Neil L, Burkhard M, Hoover E: Frequent perinatal transmission of feline immunodeficiency virus by chronically infected cats. J Virol 1996, 70:2894-2901.

82. Obert L, Hoover E: Feline immunodeficiency virus clade $\mathrm{C}$ mucosal transmission and disease courses. AIDS Res Hum Retroviruses 2000, 16:677-688

83. Burkhard M, Valenski L, Leavell S, Dean G, Tompkins W: Evaluation of FIV protein-expressing VEE-replicon vaccine vectors in cats. Vaccine 2002, 21:258-268

84. Lewis P, Nduati R, Kreiss Joan K, John Grace C, Richardson Barbra A, MboriNgacha D, Ndinya-Achola J, Overbaugh J: Cell-Free Human Immunodeficiency Virus Type 1 in Breast Milk. The Journal of Infectious Diseases 1998, 177:34-39.

85. Kaizu M, Weiler AM, Weisgrau KL, Vielhuber KA, May G, Piaskowski SM Furlott J, Maness NJ, Friedrich TC, Loffredo JT, Usborne A, Rakasz EG: Repeated intravaginal inoculation with cell-associated simian immunodeficiency virus results in persistent infection of nonhuman primates. J Infect Dis 2006, 194:912-916.

86. Howard K, Reckling S, Egan E, Dean G: Acute mucosal pathogenesis of feline immunodeficiency virus is independent of viral dose in vaginally infected cats. Retrovirology 2010, 7:2.

87. Mellors JW, Muñoz A, Giorgi JV, Margolick JB, Tassoni CJ, Gupta P, Kingsley LA, Todd JA, Saah AJ, Detels R, Phair JP, Rinaldo CR Jr: Plasma viral load and CD4+ lymphocytes as prognostic markers of HIV-1 infection. Ann Intern Med 1997, 126:946-954.

88. Rodríguez B, Sethi AK, Cheruvu VK, Mackay W, Bosch RJ, Kitahata M, Boswell SL, Mathews WC, Bangsberg DR, Martin J, Whalen CC, Sieg S, Yadavalli S, Deeks SG, Lederman MM: Predictive value of plasma HIV RNA level on rate of CD4 T-cell decline in untreated HIV infection. JAMA 2006, 296:1498-1506.

89. Gibbons J, Cory JM, Hewlett IK, Epstein JS, Eyster ME: Silent infections with human immunodeficiency virus type 1 are highly unlikely in multitransfused seronegative hemophiliacs. Blood 1990, 76:1924-1926.

90. Langlade-Demoyen P, Ngo-Giang-Huong N, Ferchal F, Oksenhendler E: Human immunodeficiency virus (HIV) nef-specific cytotoxic T lymphocytes in noninfected heterosexual contact of HIV-infected patients. J Clin Invest 1994, 93:1293-1297.

91. Rowland-Jones S, Sutton J, Ariyoshi K, Dong T, Gotch F, McAdam S, Whitby D, Sabally S, Gallimore A, Corrah T, Takiguchi M, Schultz T, McMichael A, Whittle H: HIV-specific cytotoxic T-cells in HIV-exposed but uninfected Gambian women. Nat Med 1995, 1:59-64.

92. Clerici M, Giorgi JV, Chou CC, Gudeman VK, Zack JA, Gupta P, Ho HN, Nishanian PG, Berzofsky JA, Shearer GM: Cell-mediated immune response to human immunodeficiency virus (HIV) type 1 in seronegative homosexual men with recent sexual exposure to HIV-1. J Infect Dis 1992, 165:1012-1019.

doi: $10.1186 / 1742-4690-7-49$

Cite this article as: Kumar et al., Prior mucosal exposure to heterologous cells alters the pathogenesis of cell-associated mucosal feline immunodeficiency virus challenge Retrovirology 2010, 7:49

\section{Submit your next manuscript to BioMed Central} and take full advantage of:

- Convenient online submission

- Thorough peer review

- No space constraints or color figure charges

- Immediate publication on acceptance

- Inclusion in PubMed, CAS, Scopus and Google Scholar

- Research which is freely available for redistribution

Submit your manuscript at www.biomedcentral.com/submit
C Biomed Central 